\title{
The Effect of Antibiotic Use Within the First Year of Life On 3-Year Childhood Obesity
}

\section{Yaşamın İlk Yılındaki Antibiyotik Kullanımının 3 Yaş Çocukluk Çağı Obezitesi Üzerine Etkisi}

\author{
Cüneyt Ardıç ${ }^{1}$ O Oguzer Usta ${ }^{1}$, Esma Omar' ${ }^{1}$ Cihangir Yıldız'
}

${ }^{1}$ Recep Tayyip Erdoğan University Medical Faculty, Department of Family Medicine

\begin{abstract}
Objectives: The aim of the present study was to research the effect of antibiotic use within first year of life on 3-year obesity or overweight condition in consideration of maternal obesity, birth weight, gender, the weight gained during pregnancy.

Materials and Methods: This retrospective cohort study was conducted on 182 healthy children who were born in Rize (Turkey) province and followed regularly until 3 years of age. The antibiotics used by the children within first 12 months of their life were determined through electronic health cards and the association between antibiotic use and 3-year obesity or overweight status was detected.

Results: We used logistic regression to adjust for potential confounders. In the crude analysis, risk of being overweighed and obesity was evaluated in the children who were exposed to antibiotic use within first 12 months of life in comparison within those who have not used. (odds ratio: 1.40; 95\% CI: [ 1.231.57]). After multivariate adjustment, the increased risk remained (adjusted odds ratio: 1.22; $95 \% \mathrm{CI}$ : [1.04-1.40]).

Conclusion: The results obtained indicated that risk of obesity is significantly higher in the 3- year old children who were exposed to antibiotics within first 12 months of life. Further studies may focus on prevention of obesity in the children due to antibiotic use.

Keywords: Antibiotic, childhood obesity, overweight
\end{abstract}

\section{$\ddot{O} \mathbf{z}$}

Amaç: Bu çalışmanın amacı, maternal obezite, doğum ağırlığı, cinsiyet, gebelikte kazanılan kilo dikkate alındığında, yaşamın ilk yılında antibiyotik kullanımının 3 yıllık obezite veya fazla kilo durumu üzerindeki etkisini araștırmaktır.

Materyal ve Metot: Bu retrospektif kohort çalışması, Rize (Türkiye) ilinde doğan ve 3 yaşına kadar düzenli olarak takip edilen 182 sağılıkı çocuğa uygulandı. Çocukların yaşamlarının ilk 12 ayı içerisinde kullandıkları antibiyotikler elektronik sağlık kartları ile belirlendi ve antibiyotik kullanımı ile 3 yıllık obezite veya fazla kilo durumu arasındaki ilişki tespit edildi.

Bulgular: Potansiyel karışıklıkları ayarlamak için lojistik regresyon analizi kullanıldı. Ham analizde, yaşamdan sonraki ilk 12 ay içerisinde antibiyotik kullanımına maruz kalan çocuklarda kullanılmamış olanlara kıyasla aşırı kilo alma ve şişmanlık riski değerlendirildi. (oran oranı ((OR)): 1.40;\% 95 CI: [1.231.57]). Çok değișkenli ayarlama sonrasında, artan risk kaldı (düzeltilmiş oran oranı ((AOR)): 1.22;\% 95 CI: [1.04-1.40]).

Sonuç: Elde edilen sonuçlar, obezite riskinin, yaşamın ilk 12 ayında antibiyotik uygulanan 3 yaşındaki çocuklarda anlamlı derecede yüksek olduğunu göstermiştir. Gelecekteki çalışmalar, antibiyotik kullanımı nedeniyle çocuklarda obezitenin önlenmesine odaklanabilir.

Anahtar kelimeler: Antibiyotik, çocukluk çağı obezitesi, fazla kiloluluk

\section{Correspondence / Yazıșma Adresi:}

Dr. Cüneyt Ardıç

Recep Tayyip Erdogan University Medical Faculty, Department of Family Medicine, Rize / Turkey

e-mail: drcuneytardic@hotmail.com

Date of submission: 08.05.2019

Date of admission: 30.07 .2019 


\section{Introduction}

Obesity which was defined as "global epidemics" by World Health organization (WHO) is an important health problem increasing rapidly during recent years. ${ }^{1,2}$ Prevalence of obesity has increased by 3 -fold in the last 20 years at WHO European Region including Turkey. ${ }^{3}$ Childhood obesity may continue until adulthood and increases the tendency to cardiovascular diseases, cancer and early deaths. ${ }^{4,5}$

Despite the evidences of antibiotic overuse in pediatric population, there are limited number of data discussing the effects of antibiotics on weight gaining in human. ${ }^{6,7}$ Antibiotics have short- and long-term effects both on intestinal microbiata of the infant which develops actively. The changes in the intestinal microbiata within this period may disrupt metabolic and immunological development; and such changes may have a deep effect on human health and diseases along the life. ${ }^{8}$ The evidences gathered reveal that intestinal microbiata may be associated with obesity and other metabolic disorders.9,10 Significant changes are detected in intestinal microbiata of obese patients and such changes may be presented before clinical symptoms of obesity. "Breastfeeding, maternal Body Mass Index (BMI) as well as hereditary microbial diversity may change the effect of antibiotic exposure on weight gain of the child. ${ }^{6}$

Previous studies cause to think that there is an association between antibiotic use during infancy and risk of obesity during childhood. ${ }^{12-15}$ However, effect of early antibiotic exposure on obesity was not clarified in healthy, well-nourished children. ${ }^{2}$

We researched the effect of antibiotic exposure within first 12 months of life on 3-year obesity in healthy children by evaluating some factors such as maternal BMI, birth weight of the infant, gender, socioeconomic condition of the family.

\section{Materials and Methods}

\section{Study Design}

The infants who were born in Rize province and Family health center between November 1, 2013 and September 30, 2014 were enrolled into our retrospective cohort study.

Mothers are followed-up by same family physicians during their pregnancy periods and all infants were also monitored regularly until 36 months by same family physicians. The Family Physicians who participated into the study monitored such registered infants in family health centers and recorded bodyweight-length-head circumferenceBMI at months 1, 3, 7, 9, 12, 18, 24, 30, 36 in accordance with the protocol of Turkish Health Ministry.

The data about antibiotic use state of the infants were accessed via electronic health records and the time and type of antibiotic exposure was recorded. After antibiotic types and counts used by the infants until 12 months are detected, BMI at 3 years of age was calculated and the association was investigated.

\section{Exclusion criteria}

- The infants born below 2,500 g or above 4,500 g;

- The infants who did not come to follow-up visits regularly; 
- The infants with congenital heart disease, congenital immune system failure, malabsorption syndrome and fenilketonuria were excluded.

\section{Percentile measurements}

Body length was performed through a scale mounted on the wall. Shoes of the children were taken off, they were positioned as the feet were next to each other, back, hips and heels connected to a wall and length from feet to top of the head was measured.

The bodyweight was measured after heavy clothes and shoes were taken off; a mobile scale sensitive to 100 grams was used for all children. BMI of the children was calculated by dividing the bodyweight into square meter of the body length. The BMI values detected were compared with reference range of NCHS (National Center of Health Statistics); values over percentile 85 were accepted as overweight whereas values over percentile 95 were accepted as obesity.

\section{Maternal characteristics}

All mothers participated into the study were monitored during pregnancy for at least 3 times as at least once in each trimester by family physicians. Body weights of the women before pregnancy were detected; then body weight and body length measurements at last trimester (between weeks 36 and 40); and the weight gained during pregnancy was calculated. Furthermore, body weight and length of all women were measured and BMI was calculated when their children is at 3 years of age.

\section{Statistical analysis}

SPSS (Statistical Package for Social Sciences) 21.0 program was used for statistical evaluation. The data obtained were used to calculate mean, standard deviation, ratio and frequency. Chi-square test was used for analysis of quantitative data; fischer's test was used when test conditions could not be met for Chi-square and Student's test was used for analysis of repetitive measurements. The data were provided as mean \pm standard deviation, percentage (\%) and range (min-max). the results were evaluated at significance level $\mathrm{p}<0.05$ within a confidentiality range of $95 \%$.

We used univariate and multivariate logistic regression to estimate crude and adjusted odds ratios and 95\% confidence intervals $(\mathrm{CI})$. The multivariable model was adjusted to evaluate the association between early antibiotic exposure during first 12 months and overweight, or obesity in preschool children. The $\mathrm{P}$ values below 0.05 were considered to be statistically significant. The statistical software package SPSS 21.0 (SPSS Inc., Chicago, IL) was used for data analyses.

Approval of the ethics committee for this study was obtained from the Ethics Committee of Recep Tayyip Erdoğan University Faculty of Medicine with protocol number 2018/71. In addition, informed consent forms were obtained from the mothers.

\section{Results}

Totally 312 children were enrolled into the study; and the study was completed with 182 children after exclusion criteria were employed. The infants participated into the study included $92(50.55 \%)$ boys; mean gestational age of the infants was $39.11 \pm 2.23$ and mean birth weight was $3870 \pm 635$ grams. Twenty-eight $(15 \cdot 38 \%)$ infants were exposed to 
antibiotics within first 6 months whereas 6o (32.97\%) infants used antibiotics within 12 months.

Among the infants enrolled into the study, 8.79\% $(n=16)$ were obese and $21.98 \%(n=40)$ were overweighted. Obesity or overweight state was significantly higher in the infants used antibiotics within first 6 months of life when compared with those who did not use $(\mathrm{p}<0.05)$. Furthermore, rate of obesity or overweight was higher in the babies exposed to antibiotics within first year of life when compared with those who did not use any antibiotics until 12 months of age(p<0.05) (Table 1).

Table 1. Child Characteristics and Risk for Obesity at 3 Years of Age

\begin{tabular}{|c|c|c|c|}
\hline & \multicolumn{2}{|c|}{ Mean \pm SDorpercentage $(\mathrm{N} / \mathrm{T})$} & \multirow[b]{2}{*}{$\mathbf{p}$} \\
\hline Variables & Non-obese & Obeseoroverweight & \\
\hline \multicolumn{4}{|l|}{ Infantsex } \\
\hline Male & $\% 46.03(58 / 126)$ & $\% 60.71(34 / 56)$ & 0.71 \\
\hline Female & $\% 53.97(68 / 126)$ & $\% 39.29(22 / 56)$ & 0.66 \\
\hline \multicolumn{4}{|l|}{ Antibiotic use } \\
\hline o-6 months & $\% 13.49(17 / 126)$ & $\% 19.64(11 / 56)$ & 0.04 \\
\hline 6-12 months & $\% 14.29(18 / 126)$ & $\% 25.00(14 / 56)$ & 0.03 \\
\hline $\begin{array}{l}\text { Exposure to any } \\
\text { antibiotics } \\
\end{array}$ & $\% 72.22(91 / 126)$ & $\% 55.36(31 / 56)$ & 0.21 \\
\hline \multicolumn{4}{|l|}{ Mothers' educationlevel } \\
\hline Elementaryormiddleschool & $\% 41.27(52 / 126)$ & $\% 60.71(34 / 56)$ & 0.35 \\
\hline High school & $\% 36.51(46 / 126)$ & $\% 19.64(11 / 56)$ & 0.09 \\
\hline University & $\% 22.22(28 / 126)$ & $\% 13.63(9 / 56)$ & 0.65 \\
\hline \multicolumn{4}{|l|}{ Mothers'tobaccouse } \\
\hline Yes & $\% 12.70(16 / 126)$ & $\% 14.29(8 / 56)$ & 0.12 \\
\hline No & $\% 87.30(110 / 126)$ & $\% 85.71(48 / 56)$ & 0.18 \\
\hline \multicolumn{4}{|l|}{ MonthlyIncome } \\
\hline$<500 €$ & $\% 34.92(44 / 126)$ & $\% 28.57(16 / 56)$ & 0.44 \\
\hline $500-1000 €$ & $\% 42.86(54 / 126)$ & $\% 58.93(33 / 56)$ & 0.48 \\
\hline$>1000 €$ & $\% 22.22(28 / 126)$ & $\% 12.50(7 / 56)$ & 0.51 \\
\hline \multicolumn{4}{|l|}{ Maternalage } \\
\hline$\leq 20$ & $\% 6.35(8 / 126)$ & $\% 10.71(6 / 56)$ & 0.09 \\
\hline$>20, \leq 35$ & $\% 54.76(69 / 126)$ & $\% 64.28(36 / 56)$ & 0.14 \\
\hline$>35$ & $\% 38.89(49 / 126)$ & $\% 25.00(14 / 56)$ & 0.34 \\
\hline \multicolumn{4}{|l|}{ Birthweight } \\
\hline$>2500,<4000 \mathrm{gr}$ & $\% 61.90(78 / 126)$ & $\% 53.57(30 / 56)$ & 0.06 \\
\hline$>4000,<4500 \mathrm{gr}$ & $\% 38.10(48 / 126)$ & $\% 46.43(26 / 56)$ & 0.03 \\
\hline \multicolumn{4}{|l|}{ Maternal BMI } \\
\hline Normal (BMI 18.5-24.9) & \%80.96 (102/126) & $\% 35.71(20 / 56)$ & 0.78 \\
\hline $\begin{array}{l}\text { Overweight (BMI 25- } \\
\text { 29.9) }\end{array}$ & $\% 12.70(16 / 126)$ & $\% 35.71(20 / 56)$ & 0.41 \\
\hline Obese $(\mathrm{BMI} \supseteq 30)$ & $\% 1.00(8 / 126)$ & $\% 28.57(16 / 56)$ & 0.02 \\
\hline
\end{tabular}

This shows the main variables of interest and the correlation with obese and non-obese participants at 3 -years in our cohort. N/T, number out of total; SD, standard deviation 
We divided the infants according to birth weight. Obesity or overweight state was significantly higher in the infants with birth weight between 4,000 and 4,5000 grams when compared with those with birth weight between 2,500 and $4,000(\mathrm{p}<0.05)$ (Table 1).

The odds ratio (OR) of overweighted and obese children aged 36 months with association of early antibiotic exposure during first 12 months were estimated through logistic regression (Table 2). In the raw analysis, risk of being overweighted and obesity was evaluated in the children who were exposed to antibiotic use within first 12 months of life in comparison within those who have not used. (odds ratio: 1.40; 95\% CI:[1.23-1.57]). After multivariate adjustment, the increased risk remained (adjusted odds ratio: 1.22; 95\% CI:[1.04-1.40])

Table 2. Crude and adjusted prevalence ratios of childhood overweight or obesity at 36 months for selected characteristics

\begin{tabular}{|c|c|c|c|c|}
\hline & OR & $\% 95$ CI & $\mathrm{AOR}^{1}$ & $\% 95$ CI \\
\hline \multicolumn{5}{|c|}{$\begin{array}{l}\text { Antibiotic exposure } \\
\text { o-12 months }\end{array}$} \\
\hline No & $1[\operatorname{Ref}]$ & & 1 [Ref] & \\
\hline Yes & 1.40 & {$[1.23-1.57]$} & 1,22 & {$[1.04-1.40]$} \\
\hline \multicolumn{5}{|l|}{ Infant sex } \\
\hline Boys & 1 [Ref] & \multicolumn{2}{|c|}{1 [Ref] } & \\
\hline Girls & 1,19 & {$[0.56-2.96]$} & 1,27 & {$[0.53-3.12]$} \\
\hline \multicolumn{5}{|l|}{ Birthweight } \\
\hline$>2500,<4000 \mathrm{gr}$ & $1.42^{*}$ & {$[1.07-5.49]$} & $1.32^{*}$ & {$[1.01-3.64]$} \\
\hline$>4000,<4500 \mathrm{gr}$ & 1 [Ref] & & 1 [Ref] & \\
\hline \multicolumn{5}{|l|}{ Maternal BMI } \\
\hline Normal & 1 [Ref] & & 1 [Ref] & \\
\hline Overweight+obese & $1.57^{*}$ & {$[0.96-3.83]$} & 1.45 & {$[1.35-3.98]$} \\
\hline \multicolumn{5}{|c|}{ Gestational weight gain } \\
\hline$<12 \mathrm{~kg}$ & $1[$ Ref] & & 1 [Ref] & \\
\hline$>12 \mathrm{~kg}$ & 1.17 & {$[0.56-2.96]$} & 1.12 & [0.89-2.34] \\
\hline
\end{tabular}

Odds ratios adjusted for maternal education, maternal age, monthly income, maternal tobacco use $^{*}$ :p<0.05, CI: confidence interval, OR: odds ratio, AOR:adjusted odds ratio, BMI:Body Mass Index

\section{Discussion}

The increase rates as well as affecting factors in childhood obesity all over the world are important components for determination. ${ }^{16,17}$ The results obtained in the present study indicated that early exposure to antibiotics during first year of life significantly increase the risk of overweight and obesity during early childhood.

Pathogenesis of obesity is a complex process which was not understood well. This case is same in childhood obesity. ${ }^{18}$ Role of intestinal microbiata in pathogenesis of obesity 
gradually increases and the evidences gathered indicate that microbiatas play a causative role in obesity. ${ }^{19,20}$ Ussar et al. showed that intestinal microbiata has a direct role on obesity. ${ }^{21}$ The studies conducted on animals revealed that antibiotics change the intestinal flora and cause obesity. ${ }^{22}$ Another mechanism explaining the effect of antibiotics on obesity was shown as causing insulin resistance by changing the intestinal flora. ${ }^{23}$

Azad et al.suggested in their study that risk of obesity increases in the boys who were exposed to antibiotics within first year of their lives at 10 years of age. ${ }^{15}$ Such association was not detected in girls. We determined that risk of overweight or obesity increases in the infants who were exposed to antibiotics during first year of life at 3 years of age regardless from the age. Trasenda et al. found in their study that the infants exposed to antibiotics during first 6 months of life have an increased risk of obesity at 4 years of age. ${ }^{7}$

Although mechanism of action of antibiotics on obesity was not clarified, it is generally accepted that the changes in intestinal microbiata induced by antibiotics contribute to obesity. ${ }^{23}$ A previous study showed that an increase was detected in fat mass of the mice which received microbiata transplants of the donors used low dose antibiotics whereas such condition was not detected in the mice which received fecal transplants from the donors who were not exposed to antibiotics. ${ }^{8}$ In addition, some studies revealed that the effects of antibiotics on both growth promotion and transformation capacity of food calories to body mass are significant for the animals exposed to antibiotics during early years of life. ${ }^{24}$

Another important outcome of the present study is the association between maternal obesity and obesity or overweight at early childhood.The previous studies reveal similar results with the present study. For instance, Whiteaker et al. carried out a study and detected that 2-year childhood obesity is more in the children of obese mother when compared with the children of non-obese mothers. ${ }^{25}$ In another study conducted by Leal et al. ${ }^{26}$ found that risk of obesity increased from $50 \%$ to $80 \%$ in the children of obese parents during early childhood. We detected that the children of obese mothers are obese or overweighted when compared with children of mothers with normal bodyweight $(\mathrm{p}<0.05)$. This may be explained by effect of genetics on obesity and effect of eating habits in the family on children feeding.

The strongest aspect of the present study was monitoring of the participant children at least 11 times by the same family physicians for 3 years. Measurements performed by same person eliminated possible confusions. Detection of antibiotic type and exposure time of the children from an environment where all records were kept electronically was another value adding feature. Another difference of the present study was focusing on 3-year childhood period to minimize other confusing factors that may cause obesity.

The present study had some limitations. First, we did not detect the indications for antibiotic use. This might have caused to fail to evaluate the effect of weight gain that might be dependent to previous infections. Another limitation was considering the antibiotic exposure during first years of life; determination of total antibiotic exposure for 3 years individually would increase value of the study. Lack of dietary habits of 
children and the use of antibiotics from records only may be added as other limitations.

In conclusion; the association between antibiotic exposure within first 12 months and risk of obesity during first 2 years of life was investigated in the present study. The results obtained indicated that risk of obesity is significantly higher in the 3-year old children who were exposed to antibiotics within first 12 months of life.

Cautious use of antibiotics is suggested to reduce the risk of obesity in the babies and children. Further studies may focus on prevention of obesity in the children due to antibiotic use.

\section{References}

1. Ng M, Fleming T, Robinson M, Thomson B, Graetz N, Margono C, et al. Global, regional, and national prevalence of overweight and obesity in children and adults during 1980-2013: a systematic analysis for the Global Burden of Disease Study 2013. Lancet 2014; 384(9945):766-81.

2. Cunningham SA, Kramer MR, Narayan KM. Incidence of childhood obesity in the United States. N Engl J Med 2014; 370(5):403-11.

3. World Health Organization: Childhood Overweight and Obesity. www.who.int/dietphysicalactivity/childhood; 2015.

4. Simmonds M, Llewellyn A, Owen CG, Woolacott N. Predicting adult obesity from childhood obesity: a systematic review and meta-analysis. Obes Rev 2016; 17(2):95-107.

5. Llewellyn A, Simmonds M, Owen CG, Woolacott N. Childhood obesity as a predictor of morbidity in adulthood: a systematic review and meta-analysis. Obes Rev 2016; 17(1):56-67.

6. Ajslev TA, Andersen CS, Gamborg M, Sørensen, T. I. A., Jess, T. Childhood overweight after establishment of the gut microbiota: the role of delivery mode, pre-pregnancy weight and early administration of antibiotics. Int J Obes 2011; 35:522-9.

7. . Trasande L, Blustein J, Liu M, Corwin E, Cox LM, Blaser MJ. Infant antibiotic exposures and early-life body mass. Int J Obes (Lond) 2013; 37:16-23.

8. Cox LM, Yamanishi S, Sohn J, Alekseyenko AV, Leung JM, Cho I,et al. Altering the intestinal microbiota during a critical developmental window has lasting metabolic consequences. Cell 2014;158:705-21.

9. Lemas DJ, Yee S, Cacho N, Miller D, Cardel M, Gurka M, et al. Exploring the contribution of maternal antibiotics and breastfeeding to development of the infant microbiome and pediatric obesity. Semin Fetal Neonatal Med 2016; 21:406-9.

10. Yallapragada SG, Nash CB, Robinson DT. Early-life exposure to antibiotics, alterations in the intestinal microbiome, and risk of metabolic disease in children and adults. Pediatr Ann 2015; 44(11):e265-9.

11. Mikkelsen KH, Allin KH, Knop FK. Effect of antibiotics on gut microbiota, glucose metabolism and body weight regulation: a review of the literature. Diabetes Obes Metab 2016; 18(5):444-53.

12. Bailey LC, Forrest CB, Zhang P, Richards TM, Livshits A, DeRusso PA. Association of antibiotics in infancy with early childhood obesity. JAMA Pediatr 2014; 168:1063-9.

13. Saari A, Virta LJ, Sankilampi U, Dunkel L, Saxen H. Antibiotic exposure in infancy and risk of being overweight in the fi rst 24 months of life. Pediatrics 2015; 135:617-26.

14. Murphy R, Stewart AW, Braithwaite I, Beasley R, Hancox RJ, Mitchell EA. Antibiotic treatment during infancy and increased body mass index in boys: an international cross-sectional study. Int J Obes (Lond) 2014; 38:1115-9.

15. Azad MB, Bridgman SL, Becker AB, Kozyrskyj AL. Infant antibiotic exposure and the development of childhood overweight and central adiposity. Int J Obes (Lond) 2014; 38:1290-8.

16. Orsi CM, Hale DE, Lynch JL. Pediatric obesity epidemiology. Curr Opin Endocrinol Diabetes Obes 2011; 18:14-22.

17. Stamatakis E, Wardle J, Cole TJ. Childhood obesity and overweight prevalence trends in England: evidence for growing socioeconomic disparities. Int J Obes (Lond) 2010; 34:41-7. 
18. Guyenet SJ, Schwartz MW. Clinical review: regulation of food intake, energy balance, and body fat mass: implications for the pathogenesis and treatment of obesity. J Clin Endocrinol Metab 2012; 97(3):745-55

19. Ridaura VK, Faith JJ, Rey FE, Cheng J, Duncan AE, Kau AL, et al. Gut micro- biota from twins discordant for obesity modulate metabolism in mice. Science 2013; 341(6150):1241-9.

20. Winer DA, Luck H, Tsai S, Winer S. The intestinal immune system in obesity and insulin resistance. Cell Metab 2016; 23(3):413-26.

21. Ussar S, Griffin NW, Bezy O, Fujisaka S, Vienberg S, Softic S, et al. Interactions between gut microbiota, host genetics and diet modulate the predisposition to obesity and metabolic syndrome. Cell Metab 2015; 22(3):516-30.

22. Cho I, Yamanishi S, Cox L, Methe I, Barbcho, Ilseung A, et al. Antibiotics in early life alter the murine colonic microbiome and adiposity. Nature. 2012; 488(7413):621-6.

1. 22- Mahana D, Trent CM, Kurtz ZD, Bokulich NA, Battaglia T, Chung J, et al. Antibiotic perturbation of the murine gut microbiome enhances the adiposity, insulin resistance, and liver disease associated with high-fat diet. Genome Med 2016; 8(1):48.

23. Ley RE, Backhed F, Turnbaugh P, Lozupone CA, Knight RD, Gordon JI. Obesity alters gut microbial ecology. Proc Natl Acad Sci U S A 2005;102: 11070-5.

24. Gaskins HR, Collier CT, Anderson DB. Antibiotics as growth promotants: mode of action. Anim Biotechnol 2002; 13:29-42.

25. Whitaker RC. Predicting preschooler obesity at birth: the role of maternal obesity in early pregnancy. Pediatrics 2004; 114:e29-e36.

26. Leal, D. B.,Assis, M. A. A. D., Conde, W. L., Lobo, A. S., Bellisle, F., Andrade, D. F. D. Individual characteristics and public or private schools predict the body mass index of Brazilian children: a multilevel analysis. Cadernos de saude publica, 2018; 34:e00053117. 